\title{
PELATIHAN PENGELOLAAN KEUANGAN KELUARGA BAGI KELOMPOK YASINAN IBU-IBU KOMPLEK RAHAYU JALAN PRAMUKA BANJARMASIN
}

\author{
Nailiya Nikmah ${ }^{1}$, Noor Safrina ${ }^{2}$, Lea Emilia Farida ${ }^{3}$, Hj.Nurul Qalbiah ${ }^{4}$ \\ Jurusan Akuntansi, Politeknik Negeri Banjarmasin ${ }^{1234}$ \\ nailiyanikmah@akuntansipoliban.ac.id ${ }^{1}$ safrina@akuntansipoliban.ac.id ${ }^{2}$ \\ leaemilia@akuntansipoliban.ac.id ${ }^{3}$ nurul_qalbiah@poliban.ac.id ${ }^{4}$
}

\begin{abstract}
Problems in financial matters often occur due to the inability to manage family finances. The most common thing is more expenditure than income. In addition, the failure to record income and expenditure became a major problem in managing family finances in the yasinan group of Rahayu Banjarmasin Complex. Some of the problems in terms of financial management can be formulated as follows: Imbalance between income and expenditure, inability to set family financial priorities, weaknesses in expenditure planning, weaknesses in recording and managing family financial cashflow. This community service activity was proposed with a solution in the form of family financial management training. This activity aims to provide skills to mothers in managing family finances that will improve the welfare of families and the community in general. The method used is training by giving lectures or explanations as well as training on financial management and family financial management practices / practices with simple working paper equipment prepared.
\end{abstract}

Keywords: training, family financial management, Yasinan Komplek Rahayu Group

\begin{abstract}
ABSTRAK
Permasalahan dalam hal keuangan sering terjadi disebabkan oleh ketidakterampilan mengelola keuangan keluarga. Hal yang paling banyak terjadi yaitu lebih besar pengeluaran daripada pemasukan. Selain itu, tidak dilakukannya pencatatan pemasukan dan pengeluaran menjadi masalah utama dalam pengelolaan keuangan keluarga pada kelompok yasinan ibu-ibu Komplek Rahayu Banjarmasin. Beberapa permasalahan dalam hal pengelolaan keuangan tersebut dapat dirumuskan sebagai berikut: Ketidakseimbangan antara pendapatan dengan pengeluaran, ketidakterampilan dalam menetapkan skala prioritas keuangan keluarga, kelemahan dalam perencanaan pengeluaran, kelemahan dalam pencatatan dan pengaturan cashflow keuangan keluarga. Kegiatan pengabdian masyarakat ini diusulkan dengan solusi berupa pelatihan pengelolaan keuangan keluarga. Kegiatan ini bertujuan memberikan keterampilan pada ibu-ibu dalam mengelola keuangan keluarga yang akan meningkatkan kesejahteraan keluarga serta masyarakat pada umumnya. Metode dilakukan adalah pelatihan dengan memberikan ceramah atau penjelasan serta pelatihan tentang pengelolaan keuangan serta latihan/praktik pengelolaan keuangan keluarga dengan perlengkapan kertas kerja sederhana yang sudah disiapkan.
\end{abstract}

Kata Kunci: pelatihan, pengelolaan keuangan keluarga, Kelompok Yasinan Komplek Rahayu 


\section{PENDAHULUAN}

Kegiatan Pengabdian kepada Masyarakat merupakan salah satu komponen dari Tri Dharma Perguruan Tinggi, selain dua komponen lainnya yang harus dilaksanakan dengan baik. Peran serta dosen dalam berbagai hal terkait dengan suasana akademik yang membumi dan aktivitas pengembangan sumber daya sangat diharapkan di masyarakat. Oleh karena itu, keberadaan Perguruan Tinggi tidak dapat dilepaskan dari konteks masyarakat sekitar. Perguruan Tinggi hendaknya mampu berperan sebagai agen perubahan bagi perbaikan dan peningkatan derajat hidup masyarakat. Salah satu kelompok masyarakat dalam hal ini adalah keluarga.

Keluarga merupakan lembaga sosial terkecil yang berperan serta dalam pembangunan nasional. Menurut Friedman (2010) keluarga adalah dua atau lebih individu tergabung karena hubungan darah, hubungan perkawinan atau pengangkatan dan orang-orang yang hidup dalam satu rumah tangga, saling berinteraksi, memiliki peran masing-masing untuk menciptakan serta mempertahankan kebudayaan.

Puspitawati (2012) mengutip dan menyimpulkan berdasar UU Nomor 10 Tahun 1992 Pasal 1 Ayat 10; Khairuddin 1985; Landis 1989; Day et al. 1995; Gelles 1995; Ember dan Ember 1996; Vosler 1996 bahwa sebagai unit sosialekonomi terkecil dalam masyarakat, keluarga merupakan landasan dasar dari semua institusi, merupakan kelompok primer yang terdiri dari dua atau lebih orang yang mempunyai jaringan interaksi interpersonal, hubungan darah, hubungan perkawinan, dan adopsi

Berbagai gerakan bernuansa membangun dari rumah sudah banyak dicanangkan di Indonesia. Beberapa gerakan tersebut di antaranya Indonesian strong from home yang dikenalkan oleh tokoh parenting Ayah Edi, kemudian gerakan 18.21 oleh tokoh parenting Abah Ikhsan. Hal yang sama juga sering disampaikan oleh tokoh pendidik dan penulis buku Mohammad Faudzil Adhim.

Para perempuan - dalam hal ini lebih spesifik adalah para ibu merupakan sosok yang perannya tidak bisa diabaikan begitu saja dalam peningkatan kesejahteraan keluarga. Baik para ibu yang mengabdi penuh di rumah tangga maupun para ibu yang berperan ganda dengan menjadi pekerja di luar rumah. Keduanya tidak bisa terlepas dari ikatan budaya, norma dan tata aturan yang berlaku. Nilai budaya yang berlaku di Indonesia pada umumnya adalah isteri bertugas memegang keuangan dalam rumah tangga dan suami bertugas mencari nafkah. Meski tidak sedikit pula rumah tangga yang ditopang oleh kedua belah pihak sekaligus, yaitu suami dan isteri. Dua pos pemasukan terkadang justru akan membuat pemegang keuangan menjadi bertambah tugasnya karena bertambah banyak yang dikelola.

Dipercaya untuk memegang sekaligus mengelola keuangan keluarga merupakan sebuah amanah yang tidak bisa disepelekan oleh para isteri. Hal tersebut terkesan sederhana tetapi menuntut keterampilan khusus agar keuangan keluarga dapat dikelola dengan lebih baik. Apalagi di era semakin meningkatnya harga kebutuhan pokok seperti sekarang, para ibu dituntut keahlian dan keterampilannya dalam mengatur keuangan keluarga. 
Pelatihan pengelolaan keuangan keluarga sebagai upaya peningkatan keterampilan pengelolaan keuangan keluarga oleh para ibu (istri) pernah dilakukan oleh Evi Marlina dkk (2017) yang dimuat dalam Jurnal Pengabdian untukmu Negeri serta pengabdian masyarakat yang dilakukan oleh Regina Detty dan Istiharini (2013), Fakultas Ekonomi, Universitas Katolik Parahyangan Bandung.

Salah satu kelompok ibu-ibu yang perlu ditingkatkan keterampilannya dalam mengelola keuangan adalah kelompok ibu-ibu yasinan Komplek Rahayu yang beralamat di Jalan Pramuka, Komplek Rahayu, Banjarmasin. Pada umumnya Kelompok Yasinan Ibu-ibu Komplek Rahayu ini merupakan kelompok ibu-ibu produktif dengan kisaran umur 25 sampai 55 tahun. Jumlah anggota kurang lebih 50 orang. Lebih dari 50\% merupakan ibu rumah tangga, sisanya merupakan perempuan bekerja. Rata-rata penghasilan mereka sekitar 10 juta per bulan.

Berdasarkan pengamatan dan pengalaman pada satu kelompok ibu-ibu, yaitu kelompok ibu-ibu yasinan Komplek Rahayu yang beralamat di Jalan Pramuka, Komplek Rahayu, Banjarmasin yang merupakan kelompok ibu-ibu produktif dengan kisaran umur 25 sampai 55 tahun dengan jumlah anggota kurang lebih 50 orang. Lebih dari 50\% merupakan ibu rumah tangga, sisanya merupakan perempuan bekerja. Rata-rata penghasilan mereka sekitar 10 juta per bulan. Permasalahan dalam hal keuangan yang sering terjadi disebabkan oleh ketidakterampilan mengelola keuangan keluarga cukup banyak. Hal yang paling sering muncul yaitu lebih besar pengeluaran daripada pemasukan. Ini kadang terjadi karena melakukan pembelian barang-barang yang tidak benar-benar dibutuhkan. Hal tersebut memicu permasalahan berikutnya, yaitu terlalu banyak hutang sehingga setiap bulan pemasukan justru habis untuk membayar tagihan. Selain itu, beberapa kejadian atau peristiwa tak terduga yang memerlukan dana besar seperti ada anggota keluarga yang sakit atau hal lainnya tidak dapat diantisipasi dengan baik akibat tidak ada pengaturan atau pengelolaan yang baik. Persoalan lainnya adalah kadang-kadang tidak ada pos dana untuk kebutuhan berlibur atau rekreasi padahal rekreasi juga termasuk dalam kebutuhan keluarga meski tidak perlu berlebihan. Yang paling ekstrem adalah setiap awal tahun ajaran para ibu selalu kerepotan membayar dana pendidikan untuk anak-anak apalagi jika bersamaan dengan momen libur dan hari raya.

Beberapa permasalahan dalam hal pengelolaan keuangan tersebut dapat dirumuskan sebagai berikut:

a. Ketidakseimbangan antara pendapatan dengan pengeluaran.

b. Ketidakterampilan dalam menetapkan skala prioritas keuangan keluarga.

c. Kelemahan dalam perencanaan pengeluaran.

d. Kelemahan dalam pencatatan dan pengaturan cashflow keuangan keluarga.

Dengan demikian, Tim pelaksana kegiatan Pengabdian Kepada Masyarakat kali ini berupaya memberikan pelatihan untuk melatih para ibu tersebut dalam hal pengelolaan keuangan keluarga. Melalui Program Pengabdian kepada Masyarakat, tim pelaksana memberikan pelatihan pengelolaan keuangan keluarga bagi kelompok ibu-ibu agar terampil dalam mengelola keuangan keluarga. Pengelolaan keuangan keluarga yang teratur diharapkan dapat membantu para ibu lebih baik 
memanajemen rumah tangga sehingga dapat meningkatkan kesejahteraan keluarga.

Kegiatan Pengabdian Kepada Masyarakat ini mempunyai tujuan dan manfaat sebagai berikut:

a. Menjelaskan dan memberikan latihan tentang cara pengelolaan keuangan keluarga yang baik dan benar sehingga para peserta (ibu-ibu) lebih terampil.

b. Menjalin hubungan kerja sama dan menjalin silaturahmi antara civitas akademika dengan masyarakat dalam pelaksanaan Tri Dharma Perguruan Tinggi.

c. Mengupayakan sinergitas potensi berbagai pihak yang dapat meningkatkan perkembangan masyarakat khususnya di bidang sosial ekonomi yang berbasis profesionalisme.

\section{METODE KEGIATAN}

Kegiatan Pengabdian Kepada Masyarakat ini menggunakan cara berupa pelatihan pengelolaan keuangan keluarga dengan memberikan pelatihan berupa penjelasan terstruktur tentang pengelolaan keuangan serta latihan/praktik pengelolaan keuangan keluarga dengan perlengkapan kertas kerja sederhana yang sudah disiapkan. Kegiatan ini dilaksanakan dengan tahapan rincian sebagai berikut:

a) Penjelasan tentang pentingnya skala prioritas dalam pengelolaan keuangan keluarga.

b) Penjelasan tentang pentingnya menjaga keseimbangan antara pendapatan dengan pengeluaran.

c) Penjelasan tentang pentingnya melakukan perencanaan dalam pengeluaran keluarga serta pelatihan membuat perencanaan yang baik dan benar.

d) Pelatihan pencatatan pemasukan dan pengeluaran keuangan untuk meningkatkan keterampilan pengelolaan keuangan keluarga sesuai teori akuntansi yang disesuaikan dengan pemahaman dan wawasan mitra.

Adapun yang menjadi nara sumber pada kegiatan ini adalah $\mathrm{Ibu} \mathrm{Hj}$. Nurul Mukhlisah,SE,MM dengan kepakaran di bidang akuntansi, keuangan dan manajemen keuangan. Selain itu, anggota tim pengusul juga terdiri atas para ahli di bidang akuntansi, keuangan dan manajemen serta anggaran yang senantiasa dapat diandalkan perannya dalam membantu kelancaran acara pelatihan.

Pelaksanaan kegiatan pengabdian kepada masyarakat ini dilakukan dengan pemikiran terbuka dan semangat pembelajaran yang aktif oleh seluruh komponen yang terlibat, terutama peserta yang berasal dari kelompok ibu-ibu yasinan yang menjadi mitra dalam kegiatan ini. Para ibu berkumpul di tempat yang telah disepakati sesuai kebiasaan rutin mereka dalam kelompok yasinan bulanan dengan memilih tempat strategis dan diharapkan keberkahannya, yaitu Mesjid komplek Rahayu pada waktu yang telah disepakati yaitu pada hari Sabtu, 22 September 2018. 


\section{HASIL DAN PEMBAHASAN}

Berdasarkan teori yang penyusun kutip secara langsung dari Jurnal Riset Ekonomi dan Bisnis Vol. 7 No. 2 September 2007 dijelaskan bahwa" Financial planning atau perencanaan keuangan keluarga adalah istilah yang mulai populer di Indonesia sekitar tiga sampai empat tahun terakhir. Mereka yang menekuni profesi ini menyebut dirinya sebagai Financial Planner yakni orang-orang yang mendampingi individu atau keluarga untuk menyusun rencana keuangan guna mencapai tujuan-tujuan keuangan yang telah dipilih atau ditetapkan sebelumnya. Dalam kontek ini perencanaan keuangan lebih banyak berkaitan dengan keuangan pribadi (Personal Finance) ketimbang keuangan perusahaan (Corporate Finance)."

Selain itu, artikel tersebut juga menjelaskan "Terdapat 11 alasan mengapa perencanaan keuangan perlu dilakukan oleh individu maupun keluarga, yaitu untuk melindungi diri sendiri dan keluarga dari berbagai resiko yang berdampak secara financial (seperti kecelakaan, penyakit, kematian, dan tuntutan hukum), mengurangi hutang-hutang pribadi / keluarga, membiayai kehidupan saat tidak lagi berada dalam rentang usia produktif, ini berkaitan dengan naiknya tingkat ekspektasi hidup rata - rata manusia di suatu Negara, membayar biaya-biaya yang diperlukan untuk membesarkan anak, menyediakan biaya pendidikan anak sampai ke perguruan tinggi, membayar biaya pernikahan, membeli kendaraan, membeli rumah, mampu menentukan masa pensiun dengan gaya hidup yang kita inginkan, membayar biaya-biaya perawatan yang bersifat jangka panjang, dan mewariskan kesejahteraan kepada generasi berikutnya (anak, cucu, cicit, canggah). Demikian juga dengan penelitian Walker dan Llewellyn (2000) mengenai akuntansi dalam rumah tangga : beberapa perspektif interdisciplinary yang menyimpulkan bahwa praktek akuntansi di dalam rumah tangga dan individual berpotensi sama dengan institusi publik."

Anggaran pendapatan dan belanja keluarga (APBK) merupakan jantung dari sebuah perencanaan yang baik dan efektif. Anggaran yang diperhitungkan secara benar akan memaksimalkan pencapaian sasaran maupun tujuan keuangan jangka panjang di tengah keterbatasan pendapatan. Penyusunan anggaran dilakukan melalui enam tahapan, yaitu penentuan sasaran dan tujuan keuangan, pengumpulan data keuangan, penyusunan anggaran, analisis anggaran, pelaksanaan anggaran dan peninjauan ulang dana pengendalian pelaksanaan anggaran. (Sembel et al dalam Suhartini, 2003).

Terkait akuntansi untuk organisasi nirlaba, Ikatan Akuntan Indonesia telah mengeluarkan Pernyataan Standar Akuntansi Keuangan (PSAK) Nomor 45 tentang Pernyataan Akuntansi untuk organisasi nirlaba. Menurut PSAK Nomor 45 bahwa laporan keuangan organisasi nonprofit meliputi laporan posisi keuangan pada akhir periode pelaporan, laporan aktivitas serta laporan arus kas untuk suatu periode pelaporan, dan catatan atas laporan keuangan. Laporan-laporan tersebut harus disampaikan untuk setiap periode akuntansi (satu tahun), namun bisa juga dibuat setiap bulan, triwulan, atau per semester.

Laporan posisi keuangan adalah laporan yang menyajikan informasi terkait aset/ harta/ aktiva, kewajiban/ hutang dan modal/ aktiva bersih yang dimiliki oleh 
keluarga, sedangkan laporan aktivitas keuangan keluarga adalah laporan yang menyajikan penerimaan (tidak terikat, terikat temporer, dan terikat permanen) dan pengeluaran (tidak terikat, terikat temporer, dan terikat permanen). Adapun laporan arus kas keluarga adalah laporan yang menyajikan informasi penerimaan dan pengeluaran kas yang dibagi menjadi tiga kelompok, yaitu aktivitas operasi (habis pakai dan bersifat rutin), investasi (perolehan aset tetap) dan pendanaan (perolehan dan pembayaran hutang jangka panjang), sedangkan catatan atas laporan keuangan keluarga memuat penjelasan-penjelasan yang dianggap perlu untuk masing-masing rekening yang ada di laporan posisi keuangan, laporan aktivitas dan laporan arus kas.

Kegiatan yang sudah direncanakan dapat berjalan dengan baik dan lancar. Kegiatan ini menghasilkan bertambahnya wawasan para peserta yang keseluruhannya adalah ibu-ibu. Para ibu dalam kegiatan tersebut menjadi tahu bahwa keuangan keluarga termasuk dalam hal sebagaimana keuangan di bidang lainnya yang harus dikelola dengan baik. Selain itu, secara teknis, tahapan hasil yang diperoleh atau dihasilkan melalui kegiatan ini yaitu

a) Penjelasan tentang pentingnya skala prioritas dalam pengelolaan keuangan keluarga.

Melalui tahap tersebut, para peserta kegiatan menjadi tahu bahwa skala prioritas dalam pengelolaan keuangan keluarga sangat penting. Peserta berlatih membuat daftar prioritas.

b) Penjelasan tentang pentingnya menjaga keseimbangan antara pendapatan dengan pengeluaran.

Peserta mendapatkan makna keseimbangan antara pendapatan dengan pengeluaran serta berlatih cara menjaga keseimbangan tersebut dalam mengelola keuangan keluarga.

c) Penjelasan tentang pentingnya melakukan perencanaan dalam pengeluaran keluarga serta pelatihan membuat perencanaan yang baik dan benar.

Penjelasan ini bagian penting terkait pengelolaan keuangan keluarga yang paling utama. Melakuakn perencanaan adalah langkah menuju kesuksesan.

d) Pelatihan pencatatan pemasukan dan pengeluaran keuangan untuk meningkatkan keterampilan pengelolaan keuangan keluarga sesuai teori akuntansi yang disesuaikan dengan pemahaman dan wawasan mitra.

Pada tahap ini peserta dilatih melakukan pencatatan keuangan terkait pemasukan dan pengeluaran keuangan yang terjadi dalam keluarga.

Kegiatan pengabdian kepada masyarakat ini menghasilkan luaran berupa jasa pelatihan kepada kelompok Yasinan Ibu-ibu komplek Rahayu. Pelatihan tersebut merupakan pelatihan pengelolaan keuangan keluarga. Jadi, para ibu peserta kegiatan ini mendapatkan pelatihan mengelola keuangan keluarga dengan mengisi beberapa kertas kerja yang sudah dipersiapkan. 


\section{KESIMPULAN}

Beberapa permasalahan dalam hal pengelolaan keuangan keluarga diharapkan dapat diantisipasi dengan pengelolaan yang baik sehingga dapat mencapai hal-hal sebagai berikut dalam keuangan keluarga:

1. Keseimbangan antara pendapatan dengan pengeluaran keuangan keluarga.

2. Keterampilan dalam menetapkan skala prioritas keuangan keluarga.

3. Kekuatan keluarga dalam hal ini terutama oleh para ibu rumah tangga dalam hal perencanaan pengeluaran

4. Kekuatan dan keterampilan keluarga (Para ibu) dalam pencatatan dan pengaturan cashflow keuangan keluarga.

\section{UCAPAN TERIMA KASIH}

Tim pelaksana mengucapkan terima kasih kepada berbagai pihak yang telah banyak membantu dan mendukung kegiatan ini. Kegiatan Pengabdian kepada Masyarakat ini tidak dapat terlaksana dengan baik tanpa bantuan dan dukungan berbagai pihak, di antaranya Pusat Penelitian dan Pengabdian Masyarakat (P3M) Politeknik Negeri Banjarmasin yang telah memfasilitasi terutama dalam hal pendanaan; Jurusan Akuntansi serta mitra kami Kelompok Yasinan Ibu-ibu Komplek Rahayu yang berkenan bekerja sama. Semoga semua pihak diberikan ganjaran balasan terbaik oleh Allah, Swt.

\section{DAFTAR PUSTAKA}

Detty, Regina dan Istiharini. 2013. Pengelolaan Keuangan Keluarga yang Efektif bagi Para Ibu Rumah Tangga di Daerah Dayeuh Kolot dan Manggahang, Kabupaten Bandung. Fakultas Ekonomi, Universitas Katolik Parahyangan Bandung. (Journal.unpar.ac.id/index.php/sosial/article/view/208/193).

Marlina, Evi dkk. 2017. Perwujudan Keluarga Sakinah Melalui Pengelolaan Keuangan Rumah Tangga Secara Islami. Jurnal Pengabdian untukmu Negeri Vol.1, No.2, November 2017. ISSN: 2550-0198.

Puspitawati, Herien. 2013. Konsep dan teori Keluarga. Fakultas Ekologi Manusia - Institut Pertanian Bogor.

Ikatan Akuntan Indonesia. 2016. Standar Akuntansi Keuangan. Jakarta.

Suhartini, Dwi dan Jefta Ardhian Renanta. Pengelolaan Keuangan Keluarga Pedagang Etnis Cina dalam Jurnal Riset Ekonomi dan Bisnis Vol. 7 No. 2 September 2007. E- mail :dwie_upn12@yahoo.co.id, 